\title{
Annual Report of the Chairman of the Anglo-Belarusian Society for 2012-2013
}

BY

\author{
JIM DINGLEY*
}

In recording the events of the year that has passed since the last Annual General Meeting, I wish to emphasise the sense of real continuity in the Society's activities, when they are compared to what has sometimes been referred to overenthusiastically, I sometimes feel - as its 'heyday', the 1960s and 1970s.

The Society continues to fulfil the objective stated in its By-Laws: 'diffusion, interchange and publication of knowledge relating to the Belarusian people, their land, history and culture'.

Inevitably the range of topics covered has grown, with more attention, rightly, being given to modern realia, and also to the social side of the Society's life. The list of events that follows is an excellent reflection of the way in which the Society's life has been enriched by the arrival of young Belarusians in the UK since the 1990s.

Long may the Society continue to provide a focal point for increasing contact between the peoples of the United Kingdom and of Belarus. There are many more 'heydays' still to come.

Over the year in question the Society held the following meetings, either on its own or in conjunction with other organisations:

17 May 2012 [jointly with the European Council on Foreign Relations]: 'What makes Belarus so Difficult?', discussion led by Edward Lucas (International Editor of The Economist, Senior Fellow, Centre for European Policy Analysis) and Jana Kobzova (Policy Fellow and Programme Coordinator, ECFR), with Yaraslau Kryvoi (Editor of the Belarus Digest and Secretary of the Anglo-Belarusian Society). The event was held on the premises of the ECFR.

Jim Dingley is Acting Chairman of the Anglo-Belarusian Society. 
9 June 2012: lecture by David Marples (Distinguished University Professor, Department of History and Classics, University of Alberta), 'Re-fighting the Great Patriotic War in Contemporary Belarus'.

23 June 2012: tradition Kupalle (midsummer) celebration. Special thanks go to everyone who helped to prepare the garden and the fire, and organise the flowercrowns, the singing and dancing. This event and the Christmas celebration 'Kaliady' are now fixed events in the Society's calendar.

13 October 2012: lecture by Arnold McMillin (Emeritus Professor of the School of Slavonic and East European Studies, University College London, and one of the vice-presidents of the Anglo-Belarusian Society): 'Belarusian Prison Poetry'.

24 November 2012 (jointly with the Association of Belarusians in Great Britain): event to mark the 92nd anniversary of the Slucak Armed Campaign, held on the premises of the Association.

15 December 2012: Kaliady (Christmas) celebration 'Batlejka' a folk puppet theatre presented by Pavel Šaŭcoŭ and Saša Bielavokaja.

19 January 2013: Cinema Perpetuum Mobile Festival of short films, held at approximately the same time as the festival in Minsk.

It gives me a great deal of satisfaction to know that this report will be included in the first issue of the revived Journal of Belarusian Studies. The Society is most grateful to the Secretary, Yaraslau Kryvoi, for the hard work that he has invested in making it possible for the journal to re-appear and serve as another means whereby information about Belarus can reach a wider public. The material for the first issue has been collected and is now being prepared for publication.

I would like to conclude this report on the Society's activities by extending my thanks to the Council of the Society and especially to the Secretary, Yaraslau Kryvoi, and the Treasurer, Saša Bielavokaja. Without their support the Acting Chairman could not have acted.

The Society owes a debt of gratitude to the Association of Belarusians in Great Britain for their unfailing understanding and support, and to the Belarusian Catholic Mission, in particular to Fr Siarhiej Stasievič, for permitting the Society to hold events on Mission premises. 